Ayaktan pulmoner arteryel hipertansiyon hastalarında ortalama trombosit hacmi düzeyinin klinik sonlanımlar üzerine etkisi

\title{
Impact of the mean platelet volume level on clinical outcomes in outpatient patients with pulmonary arterial hypertension
}

Kurtulus Karaüzüm, İrem Karaüzüm

Kocaeli Üniversitesi Tıp Fakültesi, Kardiyoloji Ana Bilim Dalı, Kocaeli, Türkiye

\section{$\ddot{O} Z$}

GIRIŞ ve AMAÇ: Să̆ kalp yetersizliği (KY) pulmoner arteryel hipertansiyon (PAH) hastalarında hastaneye yatışların ve ölümün başlıca nedenidir. Bu çalışmanın amacı; ayaktan PAH hastalarinda Ortalama Trombosit Hacmi (OTH) ile KY nedenli hastaneye yatış ve mortalite arasındaki ilişkiyi değerlendirmekti.

YÖNTEM ve GEREÇLER: Haziran 2011 ve Ağustos 2017 tarihleri arasında periyodik rutin kontolleri için spesifik PAH polikliniğimize başvurmuş 86 ayaktan PAH hastasından oluşan bir geriye dönük çalışma planladık. ROC analizine göre $K Y$ nedenli hastaneye yatışı öngördüren optimal OTH değeri $>8.4$ $f L$ olarak bulundu. Hastalar OTH $>8.4 f L$ ve OTH $\leq 8.4 \mathrm{fL}$ olarak iki gruba ayrıldı. Olası öngördürücüler tek değişkenli ve çok değişkenli Cox regresyon analizi ile değerlendirildi.

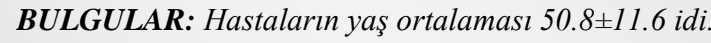
Ortalama takip süresi $27 \pm 13$ aydl. OTH $>8.4 \mathrm{fL}$ grubunda $O T H \leq 8.4$ fL grubuna göre KY nedenli hastaneye yatış belirgin olarak daha fazlayd $(\% 73.0$ 'e \%12.2, $p<0.001$ ). Ancak, tüm nedenli ölümlerde iki grup arasinda fark yoktu (\%10.8'e \%6.1, $p=0.457$ ). Tek değişkenli analizde, OTH > 8.4 $f L$ olmast ve vücut kitle indeksi ayaktan $P A H$ hastalarında $K Y$ nedenli hastaneye yatış ile ilişkiliydi $(p=0.009$ ve $p=0.047$, sirasiyla). Çok değişkenli analizde, OTH > 8.4 fL olması ayaktan PAH hastalarında KY nedenli hastaneye yatışların bağımsız güçlü bir öngördürüsü olarak bulundu ( $p=0.001$, hazard ratio $7.639,95 \%$ CI 2.414-24.178).

TARTIŞMA ve SONUÇ: Ayaktan PAH hastalarında artmış OTH düzeyi ile KY nedenli hastaneye yatış arasındaki ilişki takiplerde yüksek riskli hastaları belirlemede kullanışlı olabilir.

Anahtar Kelimeler: Ortalama trombosit hacmi, pulmoner arteryel hipertansiyon, kalp yetersizliği, hastaneye yatış

\begin{abstract}
INTRODUCTION: Right heart failure $(H F)$ is main cause of death and rehospitalization in pulmonary arterial hypertension (PAH) patients. The aim of this study was to assess the relationship between mean platelet volume $(M P V)$ with $\mathrm{HF}$ related hospitalization and mortality in outpatient $P A H$ patients
\end{abstract}

METHODS: We conducted a retrospective cohort study of 86 PAH outpatients who admitted to our special PAH clinic for periodic routine controls between June 2011 and August 2017. According to the receiver-operating characteristic analysis, the optimal cut-off value of MPV to predict HF-related hospitalization was $>8.4 \mathrm{fL}$. Patients divided to two categories as $M P V>8.4 f L$ and $M P V \leq 8.4 f L$ groups. Potential predictors were evaluated in univariate and multivariate Cox regression analysis.

RESULTS: The mean age of patients was $50.8 \pm 11.6$ years. The mean follow-up was $27 \pm 13$ months. HF-related hospitalization was found markedly higher in $M P V>8.4 \mathrm{fL}$ group than MPV $\leq 8.4$ fL group (73.0\% vs. $12.2 \%$, $p<0.001$ ), but there was no difference in term of all-cause mortality between the two groups $(10.8 \%$ vs. $6.1 \%, p=0.457)$. In univariate analysis, MPV > $8.4 \mathrm{fL}$ and BMI were associated with $H F$-related hospitalization in outpatient PAH patients $(p=0.009$ and $p=0.047$, respectively). In multivariate analysis, $M P V>8.4 f L$ was found a strong independent predictor of $H F$-related hospitalization in outpatient $P A H$ patients $(p=0.001$, hazard ratio $7.639,95 \%$ CI 2.414-24.178).

DISCUSSION AND CONCLUSION: The relationship between increased MPV level and HF-related hospitalization in outpatient PAH patients may be useful to identfy high-risk patients in follow-up.

Keywords: mean platelet volume, pulmonary arterial hypertension, heart failure, hospitalization.

İletişim / Correspondence:

Dr. Kurtulus Karaüzüm

Kocaeli Üniversitesi Tip Fakültesi, Kardiyoloji Ana Bilim Dall, Kocaeli, Türkiye

E-mail: kurtuluskarauzum@yahoo.com

Başvuru Tarihi: 12.01.2019

Kabul Tarihi: 07.02.2019 


\section{INTRODUCTION}

Pulmonary arterial hypertension (PAH) is a chronic, progressive disease which is characterized by an increased pulmonary vascular resistance and pulmonary artery pressure leading to right heart failure (RHF) (1). RHF is the main cause of death and rehospitalization in patients with PAH. Despite the advances in diagnosis and new treatment options in recent times, heart failure-related (HF-related) hospitalization and mortality rates are still high in PAH. Therefore, the knowledge of the predictors of the clinical outcomes is crucial for optimal disease management and assessment of disease severity in these patients (2). Several parameters such as presence of the pericardial effusion, low cardiac output, elevated natriuretic peptides, worse haemodynamics and dilated right atrium are associated with worse clinical status in PAH patients, have been demonsrated in previous trials (2, $3,4)$. Since the most of these predictors are invasive and/or expensive, they can not be used routinely in daily clinical practice. In this context, in outpatient PAH patients the knowledge of the simple, practical and inexpensive biomarkers may be useful in determination of high-risk patients for risk stratification. The platelets are well known to play a cornerstone role in the pathophysiology of cardiovascular diseases. The platelets are heterogenous in size and activity. The mean platelet volume (MPV), the most commonly used measure of the platelet size and activation, is a cheap and easyto-use marker $(5,6)$. MPV gives valuable information about prothrombosis and inflammation. MPV is a comparatively daily routine laboratory marker associated with atherosclerotic diseases based on inflammatory activation $(5,6)$. An increased MPV levels were demonstrated in coronary artery disease (CAD), atrial fibrillation (AF), acute myocardial infarction (AMI), cerebrovascular disease, peripheral artery disease (PAD), malignancy, ulcerative colitis, celiac disease, and Behcet disease $(5,6,7)$. Although the relationship between MPV and PAH has been studied, no previous study has evaluated the relationship between MPV and clinical outcomes in outpatient PAH patients yet $(8,9)$. Thus, we conducted this study to assess the relationship between MPV level with HF-related hospitalization and mortality in outpatient $\mathrm{PAH}$ patients.

\section{MATERIAL AND METHODS \\ Patients}

We conducted this single-center retrospective cohort study between June 2011 and August 2017 in Cardiology Department of Kocaeli University Hospital. A total of 86 consecutive outpatient PAH patients who were admitted to our special PAH clinic for periodic control visits were enrolled to this study. $\mathrm{PAH}$ were defined by a mean PAP $\geq 25 \mathrm{mmHg}$ in the presence of a pulmonary capillary wedge pressure (PCWP) $\leq 15 \mathrm{mmHg}$ and PVR $>3$ wood units. Exclusion criteria were younger than 18 years of age, groups of pulmonary hypertension other than group 1 , using of any anticoagulant or antiplatelet therapy or for any reason, the presence of any left heart disease, acute coronary syndromes in last 12 months, atrial fibrillation or flutter, overt/active hematological, immunologic, renal and hepatobilier disease, active infection, malignant diseases and end-stage other diseases which were life expectancy less than one year.

\section{Data collection}

The Cardiology Clinic of Kocaeli University Hospital has a detailed clinical database of outpatient PAH patients. The data included demographic information and medical history such as age, gender, hyperlipidemia, hypertension and diabetes mellitus were recorded during the periodic clinic control visits by physical examination and interviews with patient and family members. Blood pressure, body mass index (BMI) and 6-minute walking distance (6MWD) were recorded from physical examination findings. Information including left ventricular ejection fraction (LVEF), right ventricular enddiastolic diameter (RVEDD), pulmonary artery systolic pressure (PASP) and tricuspid annular plane systolic excursion (TAPSE) were obtained from transthoracic echocardiography evaluations. Baseline routine biochemical analysis including blood urea nitrogen, serum sodium, N-terminal probrain natriuretic peptide (NT-proBNP), and haemoglobin levels were recorded in all patients. The whole blood samples for the measurements of MPV and other hematologic parameters were collected in EDTA-containing tubes. These blood 
samples of patients were drawn in the morning after an overnight fasting in our periodic control visits. All samples were processed within 30 minutes after blood collection from the same machine. Both intra and inter-assay coefficients of variation for all measurements were $<5 \%$. The estimated glomerular filtration rate (eGFR) was calculated using the Modification of Diet in Renal Disease (MDRD) formula. Medical therapy including calcium channel blockers, endothelin receptor antagonists, phosphodiesterase type 5 inhibitors, prostacyclin analogues and prostacyclin receptor agonists were computed as being positive if the patients were taking these medications. All of these data were obtained from the national hospital database. Information including HF-related hospitalization and survival status of the patients in the study was obtained from the national hospital records or from telephone contact with the patient or family members.

The study protocol was approved by local institutional investigation committees.

\section{Statistical Analysis}

All statistical analyses were performed using IBM SPSS for Windows ${ }^{\circledR}$ version 20.0 (SPSS, Chicago, IL, USA). Kolmogorov-Smirnov tests were used to test the normality of data distribution. Normally distributed continuous variables were expressed as mean \pm standard deviation, nonnormally distributed variables were expressed as median with an interquartile range (25th-75th percentiles) and categorical variables were expressed as counts (percentages). Comparisons of normally distributed continuous variables between the groups were performed using the Student's t test and nonnormally distributed continuous variables between the groups were performed using the Mann Whitney U Test. Comparisons of cathegorical variables between the groups were performed using the Fisher ChiSquare test and Monte Carlo ChiSquare test. The most discriminative MPV cut-off point for HF-related hospitalization was calculated according to the receiver operating curve (ROC) analysis and the area under the curve (AUC) was calculated. The ROC analysis was performed to determine sensitivity and specificity of MPV cut-off point for the HF-related hospitalization. The potential clinical predictors were assessed by univariate analysis for HF-related hospitalization. Variables that significantly associated $(p<0.1)$ with HF-related hospitalization on univariate analysis were included as covariates in a multivariate Cox regression model. The cumulative HF-related hospitalization rates were estimated by Kaplan-Meier curves in MPV $\leq 8.4 \mathrm{fL}$ and MPV > $8.4 \mathrm{fL}$ patient groups. The P-values for all tests were two-sided, and statistical significance was considered at $\mathrm{P}<0.05$.

\section{RESULTS}

A total of 86 patients with PAH (25.6\% male) were included in the study. The mean age of the all patients was $50.8 \pm 11.6$ years. The mean follow-up was $27 \pm 13$ months. The ROC curve analysis of MPV is shown in Figure 1. According to the ROC curve analysis, the optimal cut-off value of MPV to predict HF-related hospitalization was $>8.4 \mathrm{fL}$. The AUC of MPV > $8.4 \mathrm{fL}$ was 0.853 ( $\mathrm{p}<0.001,95 \%$ CI 0.761 0.920 ) with a very good discriminative ability. There were no statistically differences between the $\mathrm{MPV} \leq 8.4 \mathrm{fL}$ group and MPV $>8.4 \mathrm{fL}$ group in terms of age, gender and BMI ( $\mathrm{p}=0.653, \mathrm{p}=0.986$ and $p=0.200$, respectively). Additionally, there were no differences between the two groups in terms of comorbidities including hypertension, diabetes mellitus and hyperlipidemia.

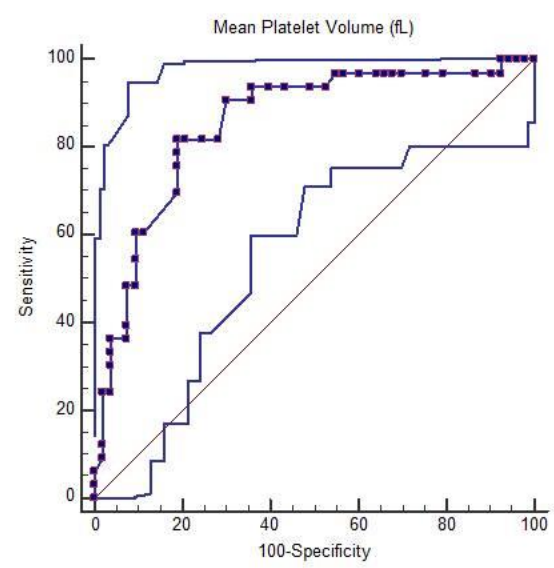

Figure 1. ROC curve analysis of the optimized MPV cutoff level for heart failure-related hospitalization in outpatient PAH patients

The study population was consisted of patients with idiopathic PAH $(n=61,70.9 \%)$, patients with PAH associated with connective tissue disease $(n=7$, $8.1 \%$ ) and patients with PAH associated with congenital heart disease $(n=18,20.9 \%)$. There was 
no statistically difference between the two groups according to the etiology of PAH ( $\mathrm{p}=0.879)$. There were no statistically differences between the MPV $\leq$ $8.4 \mathrm{fL}$ group and MPV $>8.4 \mathrm{fL}$ group in terms of eGFR, haemoglobin and sodium levels $(\mathrm{p}=0.419$, $\mathrm{p}=0.188$, and $\mathrm{p}=0.488$, respectively). The median NT-proBNP was found higher in the MPV $>8.4 \mathrm{fL}$ group than MPV $\leq 8.4 \mathrm{fL}$ group (1407 (887-2430) $\mathrm{ng} / \mathrm{L}$ vs. 1160 (622-1720) ng/L), but there was no statistically difference between the two groups $(\mathrm{p}=0.077)$. The echocardiographic parameters including RVEDD, PASP and TAPSE values were found higher in the MPV > 8.4 fL group than MPV $\leq 8.4$ fL group, but there were no statistically differences between the two groups $(\mathrm{p}=0.085$, $\mathrm{p}=0.121$, and $\mathrm{p}=0.224$, respectively). Additionally, it did not show any difference in using of $\mathrm{PAH}$ specific therapy including calcium channel blockers, endothelin receptor antagonists, phosphodiesterase type 5 inhibitors and prostacyclin analogues and receptor agonists between the two groups. The baseline clinical characteristics of study population and two patient groups were summarized in Table $\mathbf{1 .}$ Additionally, there was no difference in term of allcause mortality between the MPV $>8.4 \mathrm{fL}$ group and MPV $\leq 8.4$ fL group ( $10.8 \%$ vs. $6.1 \%, p=0.457)$, but HF-related hospitalization was found prominently higher in the MPV $>8.4 \mathrm{fL}$ group than MPV $\leq 8.4$ fL group (73.0\% vs. $12.2 \%, \mathrm{p}<0.001)$ (Table 1). In univariate analysis, MPV $>8.4 \mathrm{fL}$ and BMI were associated with HF-related hospitalization in outpatient PAH patients ( $\mathrm{p}=0.009$ and $\mathrm{p}=0.047$, respectively). Additionally, haemoglobin and eGFR levels were statistically nearly significant associated with HF-related hospitalization ( $\mathrm{p}=0.065$ and $\mathrm{p}=0.052$, respectively). Furthermore, age, sodium level, RVEDD and SPAP were not associated with HF-related hospitalization in univariate analysis. In multivariate Cox regression analysis, MPV > $8.4 \mathrm{fL}$ was found a strong independent predictor of HFrelated hospitalization $(\mathrm{p}=0.001$, hazard ratio [HR] 7.639, 95\% CI 2.414-24.178). But, haemoglobin, BMI and eGFR were not associated with HF-related hospitalization in multivariate analysis $(\mathrm{p}=0.730$, $\mathrm{p}=0.170$ and $\mathrm{p}=0.089$, respectively). The results of univariate and multivariate Cox regression analysis model for HF-related hospitalization were shown in Table 2. In the Kaplan-Meier analysis, there was a significant difference in HF-related hospitalization between the MPV > 8.4 fL group and MPV $\leq 8.4 \mathrm{fL}$ group in the follow-up ( $\log$ rank $\mathrm{p}=0.006$ ). The Kaplan-Meier analysis for HF-related hospitalization between the two groups was shown in Figure 2.

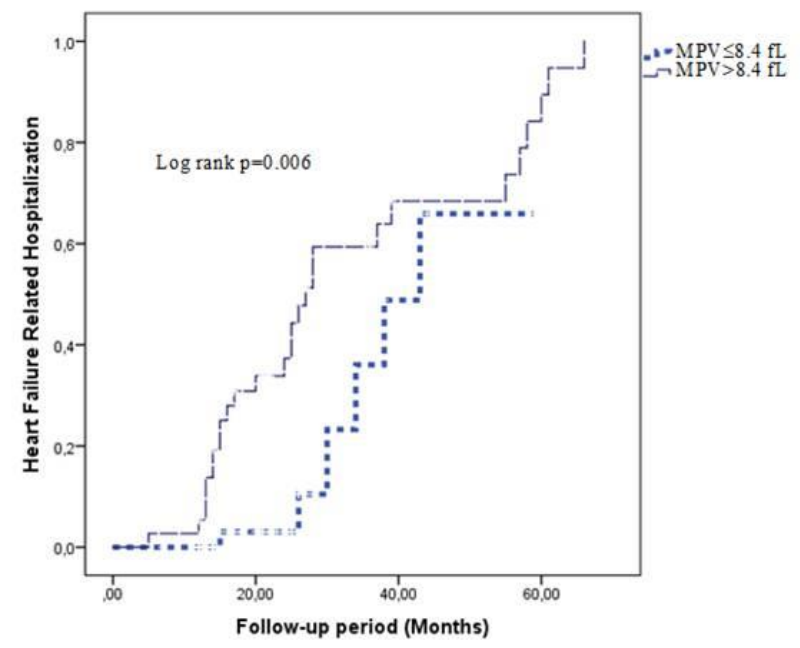

Figure 2. Kaplan-Meier analysis curve for heart failurerelated hospitalization in outpatient $\mathrm{PAH}$ patients.

\section{DISCUSSION}

In this study, we investigated the impact of the MPV on clinical outcomes in outpatient PAH patients. We found that MPV > $8.4 \mathrm{fL}$ was very significantly associated HF-related hospitalization in outpatient PAH patients. To the best of our knowledge, our study is the first to report that MPV $>8.4 \mathrm{fL}$ is a strong independent predictor of HFrelated hospitalization in outpatient $\mathrm{PAH}$ patients.

Patients with PAH and RHF often have many clinical and haemodynamic signs including syncope, cyanosis, pretibial edema, abdominal swelling or ascites, jugular venous distention, low cardiac output, decreased 6-MWD, worse functional capacity, increased NT-proBNP level and elevated right atrial pressure (1). These predictors are usually associated with worse clinical outcomes, they are used to assess the disease severity and risk stratification of PAH patients (2). The risk stratification and identification of high-risk patients are very important for optimal disease management, decision making and closely follow-up in $\mathrm{PAH}$ patients $(1,2)$. Therefore, the knowledge of 
Table 1. Baseline clinical characteristics and outcomes of the study population according to the MPV levels in outpatient $\mathrm{PAH}$ patients

\begin{tabular}{|c|c|c|c|c|}
\hline Characteristic & $\begin{array}{l}\text { All subjects } \\
\quad(\mathrm{n}=86)\end{array}$ & $\begin{array}{c}\mathrm{MPV} \leq 8.4 \\
(\mathrm{n}=49)\end{array}$ & $\begin{array}{c}\mathrm{MPV}>8.4 \\
\quad(\mathrm{n}=37)\end{array}$ & $P$-value \\
\hline Age (years) & $50.8 \pm 11.6$ & $50.7 \pm 12.4$ & $51.0 \pm 10.7$ & .653 \\
\hline Male, $n(\%)$ & $22(25.6 \%)$ & $12(24.5 \%)$ & $10(27.0 \%)$ & 986 \\
\hline Body mass index, $\mathrm{kg} / \mathrm{m}^{2}$, median (IQR) & $25.9(23.7-27.6)$ & $25.1(23.4-27.1)$ & $26.0(24.2-28.3)$ & .200 \\
\hline Pulse pressure, $\mathrm{mmHg}$, median (IQR) & $50.0(42.0-50.0)$ & $50.0(42.0-54.0)$ & $48.0(41.5-50.0)$ & .193 \\
\hline \multicolumn{5}{|l|}{ Comorbidities, $n(\%)$} \\
\hline Hypertension & $12(14.0 \%)$ & $8(16.3 \%)$ & $4(10.8 \%)$ & 677 \\
\hline Diabetes mellitus & $7(8.1 \%)$ & $3(6.1 \%)$ & $4(10.8 \%)$ & .457 \\
\hline Hyperlipidemia & $2(2.3 \%)$ & $0(0 \%)$ & $2(5.4 \%)$ & .182 \\
\hline \multicolumn{5}{|l|}{ Laboratory findings } \\
\hline eGFR, $m L / m i n / 1.73 m^{2}$ & $71.0(61.8-78.0)$ & $74.0(62.0-79.0)$ & $71.0(61.0-77.0)$ & .419 \\
\hline Haemoglobin, $g r / d l$ & $11.0(10.3-11.6)$ & $11.0(10.4-12.0)$ & $11.0(10.1-11.3)$ & .188 \\
\hline Sodium, $m E q / L$ & $134(132-136)$ & $134(131.5-135)$ & $134(132.5-136)$ & .488 \\
\hline NT-proBNP, $n g / L$ & $1290(720-1875)$ & $1160(622-1720)$ & $1407(887-2430)$ & .077 \\
\hline Six-minute walking distance, $\mathrm{m}$ & $220.8 \pm 94.1$ & $236.9 \pm 81.4$ & $199.6 \pm 106.2$ & .102 \\
\hline \multicolumn{5}{|l|}{ Echocardipgraphic features } \\
\hline RVEDD, mm, median (IQR) & $31(29-33.2)$ & $30(28-33)$ & $32(29-34.5)$ & .085 \\
\hline PASP, $m m H g$, median $(I Q R)$ & $65(50-80)$ & $60(45-75)$ & $70(52.5-80)$ & .121 \\
\hline TAPSE, mm, median (IQR) & $14(12-15.3)$ & $15(12-16.5)$ & $14(12-15)$ & .224 \\
\hline LVEF, (\%),median (IQR) & $61(60-64)$ & $62(60-64)$ & $60(60-62)$ & .153 \\
\hline \multicolumn{5}{|l|}{ Specific medical therapy, $n(\%)$} \\
\hline Endothelin receptor antagonists & $66(76.7 \%)$ & $39(79.6 \%)$ & $27(73.0 \%)$ & .644 \\
\hline Phosphodiesterase type 5 inhibitors & $17(19.8 \%)$ & $11(22.4 \%)$ & $6(16.2 \%)$ & .656 \\
\hline $\begin{array}{l}\text { Prostacyclin analogues and receptor } \\
\text { agonists }\end{array}$ & $23(26.7 \%)$ & $13(26.5 \%)$ & $15(40.5 \%)$ & .170 \\
\hline Calcium channel blockers & $22(25.6 \%)$ & $10(25.4 \%)$ & $12(32.4 \%)$ & .310 \\
\hline Etiology of PAH, $n(\%)$ & & & & .879 \\
\hline IPAH & $61(70.9 \%)$ & $36(73.5 \%)$ & $25(67.6 \%)$ & \\
\hline CTD-related PAH & $7(8.1 \%)$ & $4(8.2 \%)$ & $3(8.1 \%)$ & \\
\hline CHD-related PAH & $18(20.9 \%)$ & $9(18.4 \%)$ & $9(24.3 \%)$ & \\
\hline \multicolumn{5}{|l|}{ Clinical outcomes, $n(\%)$} \\
\hline HF-related hospitalization & $33(38.4 \%)$ & $6(12.2 \%)$ & $27(73.0 \%)$ & $<0.001$ \\
\hline All-cause mortality & $7(8.1 \%)$ & $3(6.1 \%)$ & $4(10.8 \%)$ & .457 \\
\hline
\end{tabular}

CHD-related PAH, Pulmonary arterial hypertension related to congenital heart disease; CTD-related PAH, Pulmonary arterial hypertension related to connective tissue disease; Egfr, Estimated glomerular filtration rate; HF, Heart failure; IQR, Interquartile range; IPAH, Idiopathic pulmonary arterial hypertension; LVEF, Left ventricular ejection fraction; MPV, Mean platelet volume; NTproBNP, N-terminal pro-brain natriuretic peptide; SPAP, Systolic pulmonary artery pressure; RVEDD, Right ventricular end-diastolic diameter; TAPSE, Tricuspid annular plane systolic excursion.

Table 2. Univariate and multivariate Cox regression analysis model of potential predictors for the HFrelated hospitalization in outpatient PAH patients.

\begin{tabular}{|c|c|c|c|c|}
\hline Variable & $\begin{array}{l}\text { Univariate hazard ratio } \\
(95 \% \mathrm{Cl})\end{array}$ & $P$-value & $\begin{array}{l}\text { Multivariate hazard ratio } \\
(95 \% \mathrm{Cl})\end{array}$ & $P$-value \\
\hline Age, years & $1.032(0.988-1.073)$ & .154 & & \\
\hline Haemoglobin, gr/dl & $0.720(0.508-1.020)$ & .065 & $0.921(0.575-1.474)$ & .730 \\
\hline Sodium, mEq/L & $0.942(0.849-1.044)$ & .293 & & \\
\hline $\mathrm{BMI}, \mathrm{kg} / \mathrm{m}^{2}$ & $1.153(1.002-1.320)$ & .047 & 1.131 (0.948-1.349) & .170 \\
\hline eGFR, $\mathrm{mL} / \mathrm{min} / 1.73 \mathrm{~m}^{2}$ & $0.974(0.948-1.001)$ & .052 & $0.889(0.607-1.137)$ & .089 \\
\hline RVEDD, mm & $1.013(0.950-1.081)$ & .685 & & \\
\hline SPAP, mmHg & $1.002(0.984-1.020)$ & .859 & & \\
\hline $\mathrm{MPV}>8.4 \mathrm{fL}$ & $3.337(1.346-8.276)$ & .009 & 7.639 (2.414-24.178) & .001 \\
\hline
\end{tabular}

BMI, Body mass index; Egfr, Estimated glomerular filtration rate; HF, Heart failure; MPV, Mean platelet volume; PAH, Pulmonary arterial hypertension; RVEDD, Right ventricular end-diastolic diameter; PASP, Pulmonary artery systolic pressure. 
predictors of the mortality and HF-related hospitalization is very important to improve the clinical status in these patients. A hematological blood count parameter which is named MPV reflects the platelets size and activity $(5,6)$. Larger platelets are metabolically and enzymatically more active than smaller platelets and they release important mediators $(10,11)$. These mediators play a crucial role in the process of atherosclerosis, thrombosis and inflammation. Among them, platelet factor 4, Pselectin, glycoprotein IIb/IIIa and platelet derived growth factor are technically challenging and expensive and can not be used in daily practice (10, 11). On the other hand, MPV is a very cheap, easyto-use marker and straight forward. Previous studies have been shown that increased MPV level is associated with atherosclerotic diseases such as CAD, AMI, AF, PAD, and cerebrovascular events $(6,7)$. Also, there is an interesting relationship between the MPV and many non-cardiovascular diseases including malignancies, chronic liver disease, psoriasis, Behcet disease, inflammatory bowel diseases, pre-eclampsia and systemic lupus erythematosus $(5,6)$. Additionally, it has been demonstrated that MPV level has increased in PAH patients $(8,9)$. Zheng and et al. showed that MPV levels were higher in PAH patients than age-sex matched control group (8). They also demonstrated a correlation between the elevated MPV level and worse right heart haemodynamics in PAH patients (8). This correlation was associated with severity of disease, but they did not observe statistically significant relationship between the MPV level and mortality (8). An increased MPV level showed a correlation with elevated BNP level in acute decompensated heart failure (ADHF) patients during hospital admission in Budak et al. study (12). This may reflect more serious clinical status and disease severity in these patients. Similar to Budak et al. study, NT-proBNP levels were higher in MPV > 8.4 fL group in our study, however it was not statistically significant $(\mathrm{p}=0.077)$. Kandis et al. demonstrated that MPV levels were higher in ADHF patients than stable HF patients (13). They also reported that elevated MPV was an independent predictor of inhospital mortality in ADHF patients (13). Thus, HFrelated hospitalization was markedly higher in MPV
$>8.4 \mathrm{fL}$ group than MPV $\leq 8.4 \mathrm{fL}$ group $(73.0 \%$ vs. $12.2 \%, \mathrm{p}<0.001)$, although mortality difference was not statistically significant between the two groups in our study ( $\mathrm{p}=0.457)$. The one explanation of this relationship between the elevated MPV level and HF-related hospitalization in outpatient $\mathrm{PAH}$ patients, is increased inflammatory activation. Several previous studies have suggested that MPV can be used a systemic inflammatory biomarker in many cardiovascular and non-cardiovascular disease (6). It is well known that inflammation is one of the main pathways of $\mathrm{HF}$ and $\mathrm{PAH}$ pathophysiology (1, 14). Increased inflammatory activation plays a dual role in the development of both pulmonar vascular pathology and RHF in PAH $(14,15)$. Although the exact pathophysiology underlying RHF is unclear, inflammation may play an important role, as it does in left heart failure (LHF) $(14,15)$. Joshi et al. demonstrated that increased inflammatory biomarkers were associated with worse functional capacity indicators, rehospitalization and death in PAH patients (16). Another study has shown that inflammatory biomarkers levels may be used in the assessment of treatment response in PAH patients (17). On the other hand, C-reactive protein (CRP) which is an old known inflammatory biomarker, has been studied in many previous HF and PAH trials $(18,19)$. Higher CRP levels reflect the severity of disease and are independently associated with rehospitalization and mortality in patients with $\mathrm{HF}$ and PAH $(18,19)$. Scognamiglio et al. reported that elevated CRP level was associated with worse clinical outcomes in PAH patients (20). They suggested CRP is a simple but powerful marker of mortality in PAH patients and it should be incorporated in the risk stratification and routine assessment of PAH patients (20). Furthermore, a few studies have been demonstrated a correlation between increased MPV levels and elevated CRP levels in cardiovascular disease $(21,22)$. As a result of all this data, an elevated MPV levels may indicate increased inflammatory activity as well as CRP and other inflammatory biomarkers, which are associated with worse clinical status in PAH patients. In this context, the relationship between elevated MPV levels and HF-related hospitalization is not surprising in outpatient $\mathrm{PAH}$ patients in our 
study. Second possible mechanism of our results might be sympathetic overactivation. Sympathetic activation causes shape change in the platelets and, thereby, increases MPV levels (23). Also, it has been well known that sympathetic overactivity cause to increased renin-angiotensin system (RAS) stimulation and increased catecholaminergic activity through neurohumoral activation $(24,25)$. Ozdemir et al. study demonsrated that increased MPV indicated sympathetic overactivity in patients with AMI (26). They suggested that the prognostic role of elevated MPV in patients with AMI is closely associated with sympathetic overactivity (26). On the other hand, increased neurohumoral activation are harmful and are associated with disease progression and worse clinical outcomes in HF patients $(27,28)$. Thus, Karabacak et al. demonstrated that MPV levels significantly decreased with carvedilol and nebivolol treatment in non-ischeamic HF patients (29). This important result also support that increased MPV level reflects the neurohumoral activation. Although sympathetic overactivity has been well studied in LHF, not in RHF $(27,28)$. Right ventricular adaptation to the increased afterload is the most important maladaptive response in PAH pathophysiology (30). This maladaptive response is a substantial evidence of increased sympathetic activation in PAH patients (30). This activation mainly reflects disease severity and is an independent predictor of clinical deterioration in these patients (30). In this context, the relationship between elevated MPV which is indicator of increased sympathetic activation, might be associated with HF-related hospitalization in outpatient PAH patients. Overall, elevated MPV levels are associated with the increased sympathetic and inflammatory activity, which may predispose easy decompensation of RHF and/or development of de novo RHF in outpatient PAH patients. Also, elevated MPV levels may reflect the more serious clinical status and disease severity. As a result, elevated MPV levels might be used a predictor of HF-related hospitalization in outpatient PAH patients and can be used simple in the risk stratification of outpatient PAH patients in daily clinical practice.

There are some limitations of our study. First, as this study is a single-center retrospective analysis, our results may not reflect exact data to the literature. Number of patients in our study is relatively smaller than previous PAH trials. Maybe, we did not observe significant mortality difference due to small patient number. But, it should be kept in mind that it is a PAH study. Although all patients with sinus rhythm were enrolled to the study, unknown paroxysmal AF episodes may have affected the our results. The results of our study should be confirmed with prospective, multi-center, large-scale, randomised studies.

In conclusion, a hematological blood count parameter which is named MPV, the most commonly used measure of the platelet size and activation, is a cheap and easy-to-use marker $(5,6)$. It has been demonstrated that elevated MPV levels were associated with atherosclerosis, prothrombosis and inflammation $(5,6)$. We found that MPV $>8.4$ $\mathrm{fL}$ is a strong independent predictor of HF-related hospitalization in outpatient PAH patients. The identification of high-risk patients are very important for closely follow-up and optimal disease management in PAH patients. Therefore, the knowledge of the relationship between increased MPV levels and HF-related hospitalization in outpatient PAH patients may be useful to identfy high-risk patients in daily clinical practice. This may improve clinical outcomes in these patients.

\section{REFERENCES}

1. Othman 1.Pepe S, Marasco SF, Haas SJ, Sheeran FL, Krum H, Rosenfeldt FL. Coenzyme Q 10 in cardiovascular disease. Mitochondrion. 2007 Jun;7 Suppl: S154-67.

2. Molyneux SL, Florkowski CM, Lever M, George PM. Biological variation of coenzyme Q10. ClinChem 2005;51:455-7.

3. Turunen M, Olsson J, Dallner G. Metabolism and function of coenzyme Q,Biochimica et BiophysicaActa (BBA) - Biomembranes, Volume 1660, Issue 1-2, January 2004, Pages 171-99.

4. Crane FL ve ark. Biochemical Functions of Coenzyme Q10, Journal of the American College of Nutrition 2001; 20: 591-8.

5. Ito H, Nakajima T, Takikawa R, Hamada E, Iguchi $\mathrm{M}$, Sugimoto $\mathrm{T}$ et al. Coenzyme Q10 attenuates cyanide activation of the ATP-sensitive $\mathrm{K}+$ channel current in single cardiac myocytes of the 
guinea-pig. NaunynSchmiedebergs Arch Pharmacol. 1991;344:133-6.

6. Huynh K, Kiriazis H, Du XJ, Love JE, Jandeleit-Dahm KA, Forbes JM et al.Coenzyme Q10 attenuates diastolic dysfunctions, cardiomyocyte and cardiac fibrosis in the $\mathrm{db} / \mathrm{db}$ mause model of tpe 2 diabetes. Diabetologia. 2012 May;55:1544-53.

7. Kumar A, Kaur H, Devi P, Mohan V (2009) Role of coenzyme Q10 (CoQ10) in cardiac disease, hypertension and Meniere-like syndrome. Pharmacol Ther 124:259-68

8. Langsjoen, P. H., \& Folkers, K. (1993). Isolated diastolic dysfunction of the myocardium and its response to CoQ10 treatment. ClinInvestig 71(8 Suppl), S140-4

9. Langsjoen PH, Langsjoen A, Willis R, Folkers K. Treatment of hypertrophic cardiomyopathy with coenzyme Q10. Mol Aspects Med. 1997;18 Suppl:S145-51.

10. Rickham PP. Human Experimentation. Code of Ethics of the World Medical Association. Declaration of Helsinki. Br Med J.1964;2:177

11. Quiñones MA, Otto CM, Stoddard M, Waggoner A, Zoghbi WA; Doppler Quantification Task Force of the Nomenclature and Standards Committee of theAmerican Society of Echocardiography. Recommendations for quantification of Doppler echocardiography: a report from the Doppler Quantification Task Force of the Nomenclature and Standards Committee of the American Society of Echocardiography. J Am SocEchocardiogr. 2002 Feb;15:167-84.

12. Nagueh SF, Appleton CP, Gillebert TC, Marino PN, Oh JK, Smiseth OA et al. Recommendations for the evaluation of left ventricular diastolic function by echocardiography. $\mathrm{J}$ Am Soc Echocardiogr. 2009 Feb;22:107-33.

13. Van Jaarsveld H, Potgeiter GM, Loschner A. Changes in NADH-coenzyme Q10 reductase (complex I) with autolysis in the rat heart as experimental model. Enzyme. 1986;35:206-14.

14. Folkers, K, Littarru G. P, Ho L, Runge T. M, Havanonda S, \& Cooley D. (1970). Evidence for a deficiency of coenzyme Q10 in human heart disease. Int J VitamNutr Res 40, 380-90.

15. Mabuchi H, Nohara A, Kobayashi J, Kawashiri MA, Katsuda S, Inazu A et al; Hokuriku Lipid Research Group. Effects of CoQ10 supplementation on plasma lipoprotein lipid, CoQ10 and liver and muscle enzyme levels in hypercholesterolemic patients treated with atorvastatin: a randomized double-blind study. Atherosclerosis. 2007 Dec;195:182-9.

16. Hughes K, Lee BL, Feng X, Lee J, Ong CN. Coenzyme Q10 and differnces in coronary heart disease risk in Asian Indians and Chinese. Free RadicBiol Med. 2002 Jan 15;32:132-8.

17. Lagendijk J, Ubbink JB, Vermaak WJ. Measurement of the ratio between the reduced and oxidized forms of coenzyme Q10 in human plasma as a possible marker of oxidative stres. J Lipid Res 1996;37:67-75.

18. Yamashita S, Yamamoto Y. Simultaneous detection of ubiquinol and ubiquinone in human plasma as a marker of oxidative stres. Anal Biochem 1997;250:66-73.

19. Lagendijk J, Ubbink JB, Delport R, Vermaak WJ, Human JA. Ubiquinol/ubiquinon ratio as marker of oxidative stres in coronary artery disease. ResCommunMolPatholPharmacol. 1997 Jan;95:11-20.

20. Ruiz-Jiménez J, Priego-Capote F, MataGranados JM, Quesada JM, Luque de Castro MD. Determination of the ubiquinol-10 (coenzyme Q10) in human serum by liquid chromatography tandem mass spectrometry to evaluate the oxidative stress. J Chromatogr A. 2007 Dec 21;1175:242-8.

21. Miles MV, Horn PS, Morrison JA, Tang PH, DeGrauw T, Pesce AJ. Plazma CoQ10 refernce intervals, but not redox status, are affected by Gender and race in self-reported healthy adults. ClinChimActa 2003;332:123-32.

22. Miles MV, Horn PS, Tang PH, Morrison JA, Miles L, DeGrauw T et al. Age-related changes in plasma coenzyme Q10 concentrations and redox state in apparently healhy children and adults. ClinChimActa 2004;347:139-44.

23. Kumar A, Kaur H \& Mohan V (2007). Coenzyme Q10 in isolated diastolic heart failure in hypertrophic cardiomyopathy (HCM). The 5th Conference of the International Coenzyme Q10 Association, Kobe Japan.

24. Ghirlanda G, Oradei A, Manto A, Lippa S, Uccioli L, Caputo S, et al. (1993). Evidence of plasma CoQ10-lowering effect by HMG-CoA reductase inhibitors: a double blind, placebocontrolled study. Clin Pharmocol J 33: 226-9.

25. Silver MA \&Langsjoen PH (2003). Statin cardiomyopathy: a potential role for coenzyme Q10 therapy for statin induced changes in diastolic LV performance: description of a clinical protocol. Bio factors $18(1-4), 125-7$. 
26. Silver MA, Langsjoen PH, Szabo S, Patil H, Zelinger A. Effect of atorvastatin on left ventricular diastolic function and ability of coenzyme Q10 to reverse that dysfunction. Am J Cardiol. 2004 Nov 15;94:1306-10.

27. Chew GT, Watts GF, Davis TM, Stuckey BG, Beilin LJ, Thompson PL et al. Hemodynamic effects of fenofibrate and coenzyme Q10 in type 2 diabetics subjects with left ventricular diastolic dysfunctions. Diabetes Care. 2008 Aug;31:1502-9. 